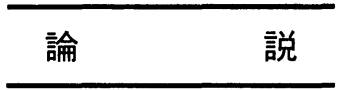 \\ 中枢性めまい病変に関する臨床的知見
}

\author{
竹川勇 \\ Clinical Neurotological Findings in Cases of \\ Vertigo of Central Origin
}

\section{Isamu Takeyama}

(St. Marianna University School of Medicine)

In 208 patients with vertigo of central origin diagnosed by the history of vertigo or dizziness, radiological findings and surgery, the diagnostic significance of the clinical neurotological findings was analyzed. Among the neurotological examinations, the deviation test, the stepping test, the righting reflex, the tests of spontaneous, positional, and positioning nystagmus were very important for the diagnosis of central lesions. Nystagmus caused by changes in head position or headshaking in the horizontal and vertical plane was manifested, and then vertical components were found in cases of cerebral vascular circulation disorder or vertebro-basilar insufficiency. In cases of brain tumor, especially acoustic tumor, OKN showed a hyporeactive or dysmetric pattern, and the ETT or pursuit eye movement test showed a saccadic or ataxic pattern. In the OKN test decrease of the slow phase velocity was significant in cases of vertigo of central origin. In cerebral arteriosclerosis or cerebral vascular circulation disorder, I examined erythrocytes, leucocytes, hemoglobin, hematocrit, fibrinegen, cholesterol, lipid and blood-glucose levels. In many cases the erythrocyte count was $500 \times 10^{4}$ or over, the hematcrit over $45 \%$ and the fibrinogen level over $300 \mathrm{mg} / \mathrm{dl}$; in $63.6 \%$ of all cases there was one abnormal blood value. Therefore, I considered that an increase of the blood viscosity together with an abnormality in the cranial vessels caused insufficient circulation in the brain which in turn caused dizziness or vertigo.

Key words: vertigo of central origin, neurotological examination, eye symptoms of central lesions, blood viscosity and central angiogenic disorders

はじめに

めまいを訴える症例は近年增加の傾问にあ

り,なかでも老人化社会汇進みつつある現状で は脳動脈硬化症や脳梗塞など脳循環不全に伴
う，いわゆる中高年層のめまいは避けて通机な い課題と言えよう。これらは末梢性好まいより もむしろ中枢性病変を主体としているととが多 く, 今回, 著者は中枢性病変としてのめまいを 
取り上げ，郜床的な観点から中枢性めまい将変 の自・他覚的所見などについて触れてみたい.

\section{対 象}

ここで取り报った症例は過去 2 年間に本学耳 鼻咽喉科外来にて他科からの依頼された症例も 含めて, めまい外来を受診し, 平衡機能検査を 施行した症例であり，てのうち末梢性めまい症 例を除外した 208 例について検讨してみた。

中枢性めまいと区分した根拠には，明らかな 頭蓋内病変や神経学的徵候を有するあのは当然 のとととしているが，末梢性めまいとは異るめ まいや眼振の性状（持続性，進行性，異常眼連 動や垂㨁性成分を有する）あるいはなんらかの 神経学的症状 (知覚異常, 竨痛, 一過性の脳神 経:症:状など）を示しためまい症例む中枢性めま いとして取り披った。

こ机らを一括して表 1 に示した。

\section{自・他覚的所見}

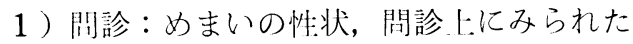
症状

めまいは自覚的な祉状であり，患者によりそ の泝えは多㥞であるが，めまいを大别して「回 転性」と「非回転性」とに区分し，前者は水梤

\section{表 I 対象症例 (1984.1 1986.7)}

\begin{tabular}{|c|c|c|}
\hline \multirow{4}{*}{ A } & 脳動脈硬化 & 28例 \\
\hline & 椎骨脳底動脈循環不全 & 25例 \\
\hline & 脳腫煌 & 13例 \\
\hline & TIA & 6例 \\
\hline グ & 脳楩塞 & 6例 \\
\hline ル & 寻骾小脸変性疲: & 4例 \\
\hline 1 & 多発性硬化症: & 2例 \\
\hline 1 & 小脳出血 & 1 例 \\
\hline フ & Wallenberg & 1例 \\
\hline & 前下小脳動脈循環不全 & 1例 \\
\hline & & 87 例 \\
\hline \multirow{5}{*}{$\begin{array}{l}\mathrm{B} \\
\text { グ } \\
\text { ル } \\
1 \\
\text { フ }\end{array}$} & 脳循環不全 & 65例 \\
\hline & その他の中枢疾患 & 22例 \\
\hline & その他の変性, 萎縮疾患 & 1例 \\
\hline & 彰断不確定 & 33例 \\
\hline & & 121例 \\
\hline
\end{tabular}

前庭性に多いことが従来からいわれているが， 今回の中枢性めまい症例についてめまいの性状 をみると，確定診断のついた87例においては， 回転性27例 (31.8\%)，非问転性60例（68.2\%） であり，中枢性として取り扱ったB群 121 例に おいては回転性43例 (35.9\%)，非回転性78例 （64.5\%）であった（表 2).いずれ屯非回軒 性のめまいが多かったが，非回転性のなかでも 浮動性めまいが大多数を占めており，てのなか には不安定感，動摇感，酩酹感，脱力感など, いわゆるめまい感といった表現も多くみられ， めまいに対する恥きとり方として，めまいの具 体性について聴取することが大切であろう。

閤診は臨床医家にとって重要であることは言 を俟たないが，とくに神経系疾患に関わる病歴 は極めて大切であることは周知の通りで，神経 系疾患のなかには上手に聴取された病歴だけで 診䉼が可能な疾患むあり，適確な病歴聴取によ り病態解明への第一歩が成り立つと考えられ, めまい疾患においても同様である.

めまいの性状，めまいの起乙り才，めまいの 唀因, めまいと随伴症状, 蝸牛症. 状との関連, 神経学的症状の有無などをそれぞれの患者の知 識水準に合せた聴きとり才をしないと正しい病 歴が得られないとともあり，また陪学用語や裴 垷屯素人に判断し理解できる程度の内容にしな がら適切な問診を行うことが大切である。

今回の症例にみられた一般神経学的症状は表 3 亿示したが，知覚異常が $11 \%$ であり，このな かには顔面知覚の異常や異和感，手足のしびれ なども含まれており，少行障害は10\%と次いで 多くみられ，乙のなかには水平面での歩行のみ ならず，上下の際，例えば階段の昇降時の不安

表 2 めまいの性質

\begin{tabular}{c|c|c}
\hline & 回転性 & 非回転性 \\
\hline A群 & $27(31.8 \%)$ & $60(68.2 \%)$ \\
B群 & $43(35.5 \%)$ & $78(64.5 \%)$
\end{tabular}




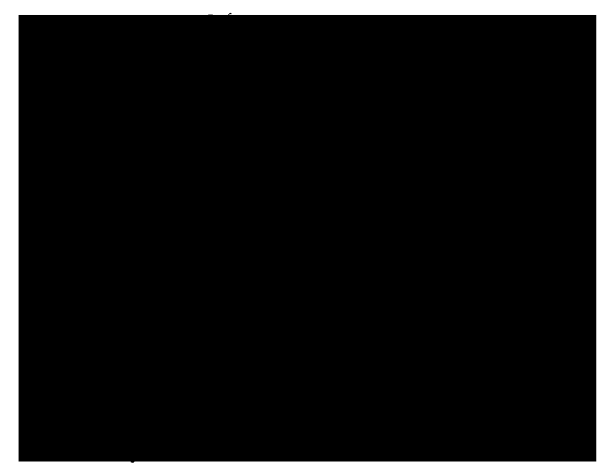

転移性:小脳腫煌（45才，女性）例

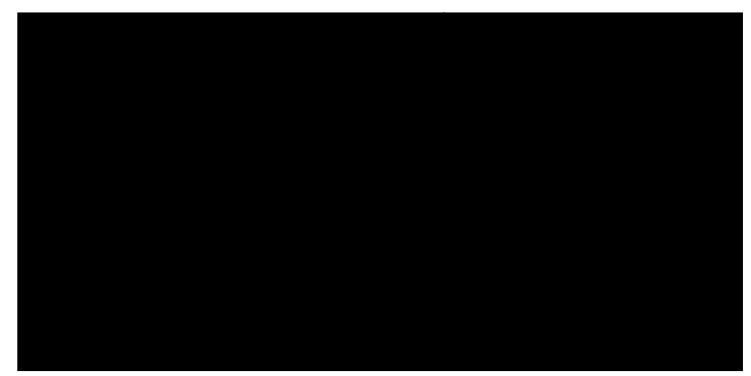

:必神経腄崲（22才，男性）例
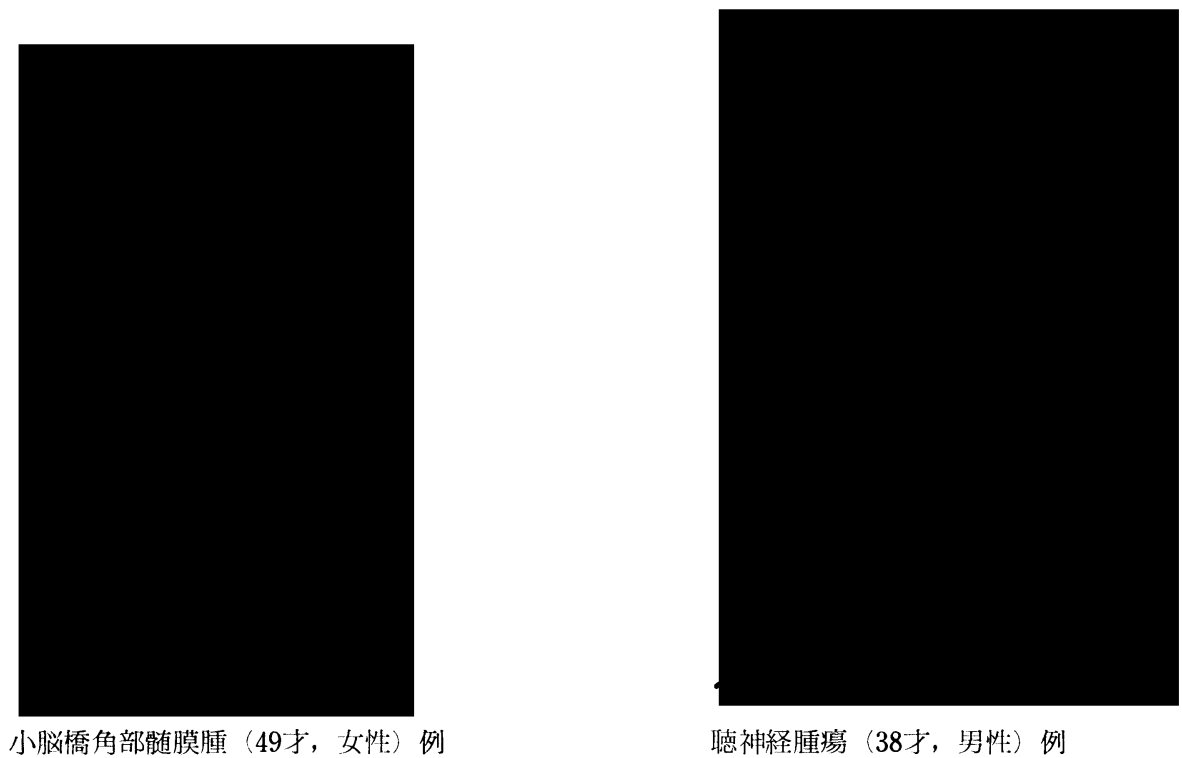

聴神経腫場（38才，男吽）例

図｜中怄性病変を有する症例の書字: 
定，よろめきなどむ含まれており，より具体的 な問診上の聴取によって異常な自覚症状の摘発 が可能となり，めまい病態の把层をより核心に 近づけることができる.

2 ）偏倚，立直り障㗉の所少

めまいを派える患者はその歼んよ゙が軀幹や叫 肢の平衡障篔を伴うので，めまいの客観的評価 として偏倚, 立直り検相の有用性がとりあげら れている.

中枢性めまい例，とくに脳幹や小脳性病変に おいては䡒字や足踏み検查にて，失調性あるい は振戦様の所見を示すことは以前より指摘され ているところで，今回の検討にて転移性小脳腫 瘍や小脳橋伯部腫場の症:例では特微的な失淍性: 文字が罗い出されたが（図1），その他，ト下 の文字が近损ないしは混入するもの，あるいは 行を進めるにつ机青字の偏倚力们が転換する屯 のなどもみられ，乙れらは中枢性障夆の病変を 有する㾟例の胃字の一種之思われ，肯字の質的 な内容も参考にする必要があ万う.

步字検查之同程度に足踏検査屯意義はある が，上肢，下肢に対する偏倚検査として前者は 平面的な偏倚検查であり，後者は立体的な偏倚 検查とも言える。处踏検查では正而頭位のみで なく, 頭位変化, 即与右傾頭位, 左傾䫓位を保 つことにより编倚の異常性をより強く罗い出す 方法屯提唱されており，末梢性为まい将変にお

表 3 自覚的障圊（症状）の頻度: (聴覚障害を除く)

\begin{tabular}{|c|c|}
\hline 知覚異常 & $11 \%$ \\
\hline 步行障㟟 & $10 \%$ \\
\hline 言語障害 & $8 \%$ \\
\hline 複＼cjkstart視 & $7 \%$ \\
\hline 䀻下障圊 & $3 \%$ \\
\hline 㫷字障罣 & $2 \%$ \\
\hline 意識障告 & $1 \%$ \\
\hline \multicolumn{2}{|l|}{ その他 } \\
\hline 頭痛，頭重感 & $12 \%$ \\
\hline 肩こり & $9 \%$ \\
\hline のぼせ & $7 \%$ \\
\hline
\end{tabular}

いてはその信頼度む高い。

今回，取り扱った中枢性病変のうち，恥神経。 腫瘍の 4 例は表 4 の如く, 頭位変化による足踏 検查を行い二つの傾问がみられた。即ちi）健 側に頭を傾斜して足踏を行うと健側への回転角 度が患側のそれより大である。 ii）患側に頭を 傾斜した際にも健側への回転角度が患側のそれ より大である。これらの症例は手術的にも腫瘍 は確認され，その大きさは $30 \mathrm{~mm}$ 前後を示してい た。また他の脳腫瘍例においても同様の傾问が みられ，術後にむ同一検査を施行した三文神経 腫瘍例では術前とは逆の所見を呈しており，末 梢性めまい病変（例えばメニエール病）にみら れる湏位傾斜の場合とは相反した所見がこれら 川枢性病变のめまい症例にみられた事実として 與味深い。

许值り反射の検查も体平衡の検查法として重 視され，近年は而心動摇検查が普及しつつあ り，めまい症例における平衡障皆を画心動搯の 当㢷加ら客锥的に計测しようという試みがなさ れている。

円1枢性めまい疾患は末梢性めまい例に比し多 彩であるが，雨心動摇の面から動摇の大きさ， 勘摇の型，動摇速度などをみると，中枢性めま

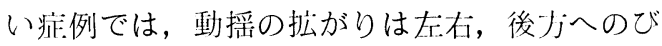
まん性の搯れが大きく，動摇面積屯広く，動摇 速度は増大するが间剘は緩やかな傾向を示して

表 4 頭位変化による足踏検査

\begin{tabular}{|c|c|c|c|c|c|}
\hline \multirow{2}{*}{ 疾 患 名 } & \multirow{2}{*}{ 年㱓 } & \multirow{2}{*}{ 性 } & \multirow{2}{*}{ 患側 } & \multicolumn{2}{|c|}{ 回転角度 } \\
\hline & & & & 右傾 & 左傾 \\
\hline 聴神経腫瘍 & 50 & M & 左 & 右 $90^{\circ}$ & 左 $30^{\circ}$ \\
\hline " & 38 & M & 有 & 左 $150^{\circ}$ & 右 $45^{\circ}$ \\
\hline " & 39 & $\mathrm{~F}$ & 左 & 右 $20^{\circ}$ & 右 $90^{\circ}$ \\
\hline " & 62 & M & 左 & 右 $110^{\circ}$ & 有 $60^{\circ}$ \\
\hline 副神経鞘腫 & 58 & $\mathrm{~F}$ & 左 & 左 $45^{\circ}$ & 左 $70^{\circ}$ \\
\hline 第 IV脳室腫瘍 & 42 & $\mathrm{~F}$ & 左 & 右 $120^{\circ}$ & 右 $90^{\circ}$ \\
\hline 三义神経鞘腫 & 22 & M & 左 & $\begin{array}{l}\text { 右 } 45^{\circ} \\
\text { 左 } 30^{\circ}\end{array}$ & $\begin{array}{l}\text { 有 } 30^{\circ} \text { (術前) } \\
\text { 左 } 60^{\circ} \text { (術後) }\end{array}$ \\
\hline
\end{tabular}


いる（図 2 ).

3 ) 眼振所昌

眼振，注視眼振，頭位眼振（表 5 ）

眼振検査はめまい疾患に対する各種検査の中 でその有用性は高く，中枢性めまい例では多彩 な眼振所見を示すととも多い。また異常眼運動 が中枢性病変に特徵的であるとともよく知られ ているとてろである。今回の対象とした中枢性 めまい症例に対して行った眼振所見についてみ ると, 自発眼振, 注視眼振, 頭位眼振などは $\mathrm{A}$
群，B群にほぼ同率にみられたが，B群にやや 高い理由は, A 群が神経学的徴候や再像診断な どからある程度の確定診断がされているが， B 群では中枢性病変を疑わせる所見として, 後述 の視標追跡検查や視運動眼振検査などの所見之 併せ，ての眼振所見を参考にしながら中枢性疾 患を考虑したためである。

頭位変換眼振検查においては憼垂頭位で下眼 睑向きの垂直成分を示した症例はテント下病変 の約65\%にみられており，実地臨床でも有用性

表 5 自発眼脤, 注視眼振, 頭位眼振の出現頻度

\begin{tabular}{|c|c|c|c|c|c|c|c|c|c|c|c|}
\hline & 自発眼振 & 水平性 & 垂直性 & 回旋性 & $\begin{array}{l}\text { 異常眼 } \\
\text { 運動 }\end{array}$ & & 注視眼振 & 固定性 & $\begin{array}{l}\text { 注視广了 } \\
\text { 向性 }\end{array}$ & 垂直性 & その他 \\
\hline A群 & $\begin{array}{c}43 \text { 例 } \\
(49.4 \%)\end{array}$ & 27 & 3 & 3 & 10 & A群 & 33例 & 13 & 8 & 6 & 6 \\
\hline B群 & $\begin{array}{c}50 \text { 例 } \\
(41.3 \%)\end{array}$ & 23 & 13 & 4 & 10 & B群 & 45例 & 14 & 8 & 13 & 10 \\
\hline
\end{tabular}

\begin{tabular}{|c|c|c|c|c|c|c|}
\hline & 頭位眼振 & 广j向固定性: & $\begin{array}{l}\text { 卢向交代性 } \\
\text { 上行性 }\end{array}$ & $\begin{array}{l}\text { 方向交代性 } \\
\text { 下行性 }\end{array}$ & 垂直州: & その他 \\
\hline A群 & 63 例 $(72.4 \%)$ & 22 & 7 & 9 & 12 & 13 \\
\hline B群 & 82 例 $(67.8 \%)$ & 18 & 14 & 12 & 20 & 18 \\
\hline
\end{tabular}

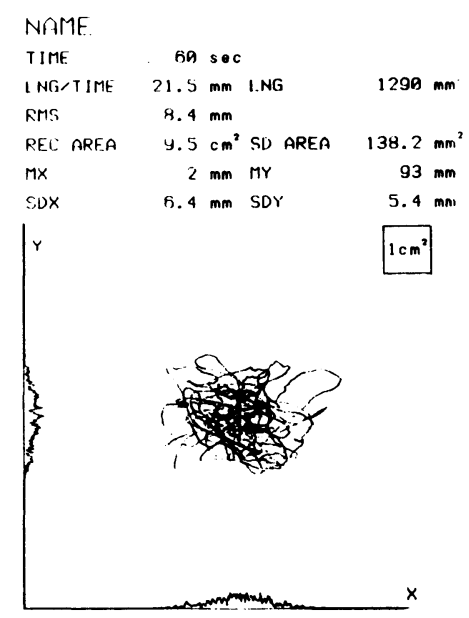

三文神経腫煬（35才，女性）例の重心動摇

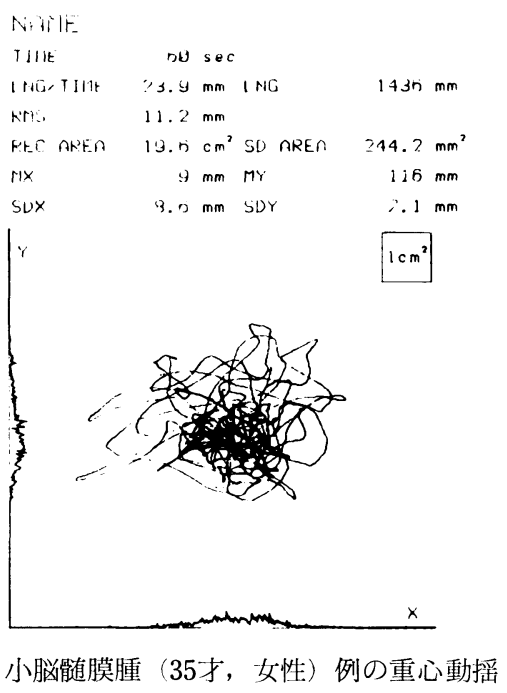

図 2 STABILOGRAPH 
の高い検梄法と言える。

その他, 㖽振り眼振検植法として, 頭部振動 负荷を加えて誘発される眼振所思をみると，中

$$
\text { 广注: }
$$

座位，フレンツェル眼錶使用

振幅: 約 90 度

回数：20往復（約 15 移間）

1 , 前屈 $30^{\circ}$,ドイツ水平面左右水平方向（せと略）
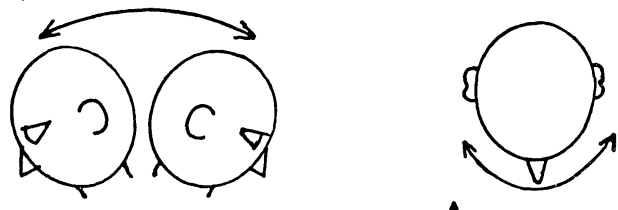

2 , 正頭位矢状面 前後水平方向（
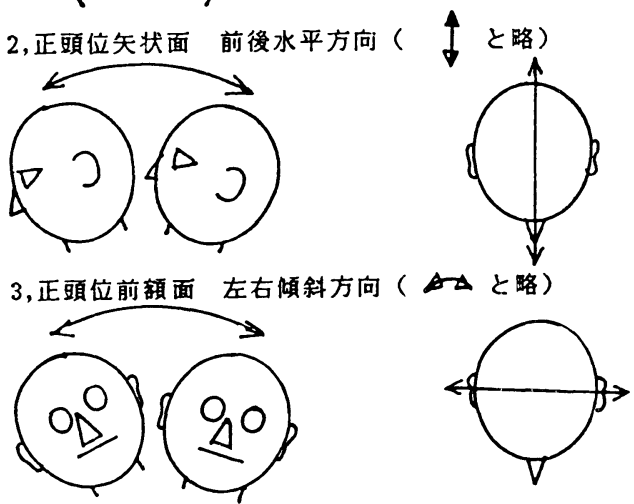

枢性めまい例の40例中23例（57.5\%）に眼振が 解発され（表 6 )， とくに前後方向への韻部振 動を加えた症例では下问き垂直性あるいは斜行 性:の成分を示し（表 7 )，乙れらの症例は大部 分が椎骨脳底動脈循噮不全や脳動脈㹬化症酒基 づく脳循環不全例であったととは，前述の頭倍 変換眼振検查でみられた所見と併せ注目したい 知見亡思われる。

视情を用いた眼球遇動検悀

㖄球速動のなかでも衝動性眼进動（saccade） 之润動性追跡服过動（pursuit）の観点から视

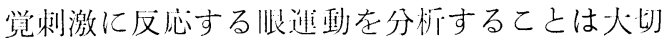
である。ここでは蚛神経腫瘍例（24才，火性） に打ける三点父互および視情追跡でみら机た肶

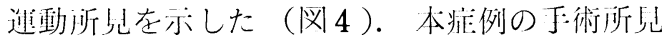
では腫瘍は $30 \mathrm{~mm}$ 人で，上少は V 神䋂に，ドうは

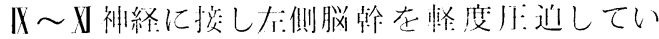

表 6 頭振り眼振検査による眼振発現率

\begin{tabular}{|c|c|c|c|c|}
\hline \multirow{3}{*}{$\begin{array}{r}\text { 中枢性 } \\
40\end{array}$} & 脳血管障害 & 30 & \multirow{3}{*}{$\begin{array}{c}23 \\
(57.5 \%)\end{array}$} & 17 \\
\hline & 頭部外傷後遺症: & 3 & & 1 \\
\hline & その他 & 7 & & 5 \\
\hline
\end{tabular}

図 3 頭拢り服振湌查法:

表 7

\begin{tabular}{|c|c|c|c|c|c|}
\hline & 疾 & 年粭 & 性 & H.S.T.の種類 & H. S. N \\
\hline 1 & 膇動脈便化症 & 61 & 男 & 1 & $\$$ \\
\hline 2 & 脑動脈硬化症 & 42 & 女 & $\Delta$ & 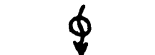 \\
\hline 3 & 椎骨脑底钦脈腯琂不全 & 58 & 女 & 1 & $\downarrow$ \\
\hline 4 & 高血圧 & 70 & 女 & 1 & 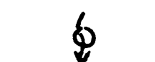 \\
\hline 5 & 椎骨脂底動眽循曆不全 & 71 & 女 & $\leftrightarrow$ & $\downarrow$ \\
\hline 6 & $\begin{array}{l}\text { 脂腫瑒 } \\
\text { (小腷橋角部腫場) }\end{array}$ & 67 & 女 & 4 & $\downarrow$ \\
\hline
\end{tabular}




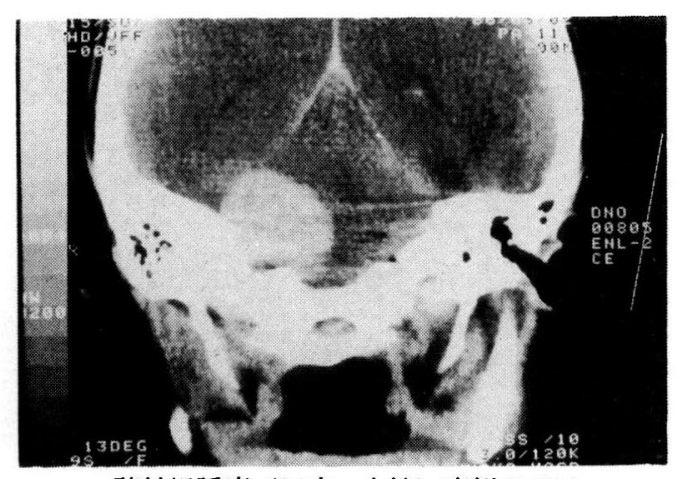

聴神経腫湯（24才，女性）症例の C T

a

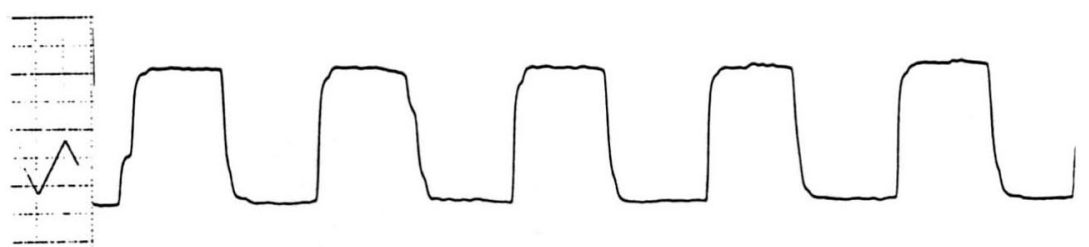

b

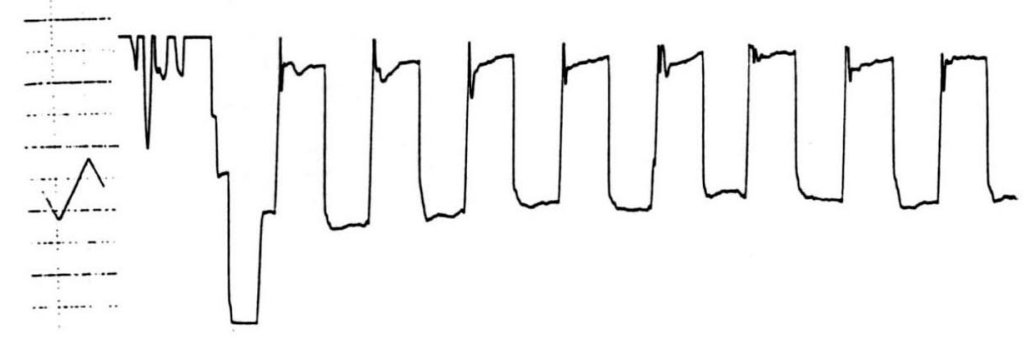

c

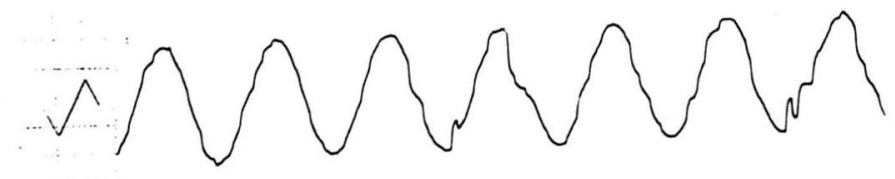

d

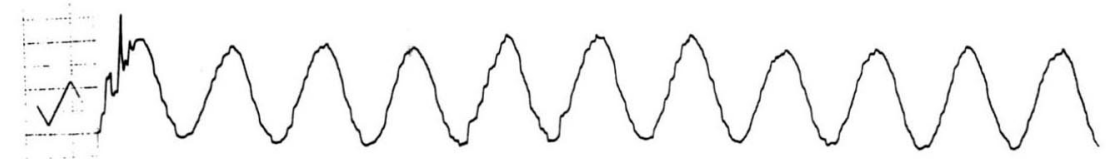

同症例における視標を用いた眼球運動検査所芫

a ) 水平性二点交互試験による眼球運動：右向き眼球運動の停止時に hypometric の所㫕をみとめる

b ）垂直性二点交互試験：上向きに hypermetric の所見をみとめる

c）水平性視標追跡運動：saccadic pattern を示す

d）垂直性視標追跡運動：上向きに saccadic 
た.

二点交互に祝線を変えた水平性 saccade で は，右问きにやや hypometric，左向きで hypermetric の眼運動を示し, 垂直性の二点交互 试験でも同様の dysmetric 在榎度ながらみ上 めている. pursuit では水平性, 垂直性のいず れにも saccadic pattern を示している. 垂直 軸における追跡眼連動と水平軸の追跡腿運動の システムは異るものと思われるが，本例では小 脳橋角部にみられた巨大な腫場による脳幹，小 脳への影曏を反映しているものと言えよう。

次は大:小脳橋角部䏣膜腫（53才，女性）の一
例であるが，手術所見では小脳外側面との慗着 が著しく, 中小脳䑤とも癒着し, 脳幹にも波及 L， IX，X神経の前方から延䯣前方に入り込ん でいたことがみられている.

本例での pursuit では saccadic と ataxic の混合した pattern を示し, 後述の視運動性: 腿振所見では急速相の解発が著しく抑制され， 綏徐相速度も低速より上昇がみられず，また祝 標刺激に対し両方向に向う不規則な視遇動哏振 在示した。

\section{视速動性眼振}

小枢性めまい病変においては視遇動性腿振に

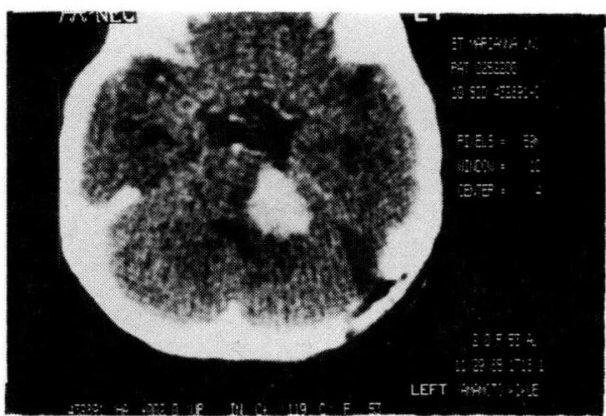

小脳橋角部蹃膜腄（53才，女性）症例の C T

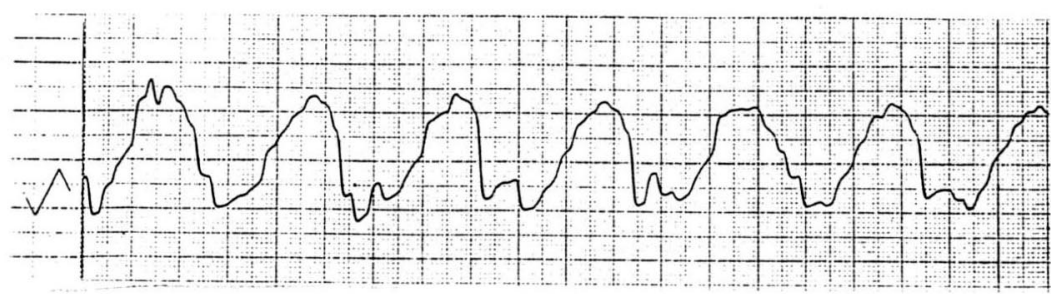

同症例の ETT : saccadic と ataxic の混合型

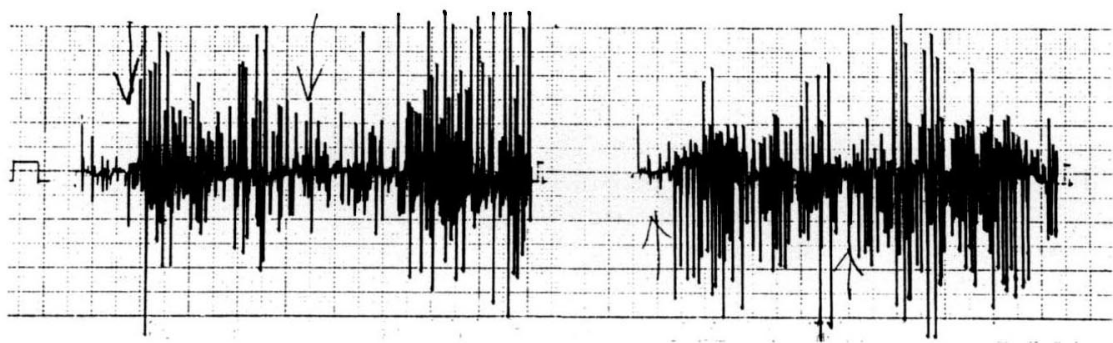

同症例の OKP :

図 5 
異常所見が高率にみられ，とくに脳翰，小脳领 域の病態診断に対しその有用性はは高い.

今回，脳腫瘍症例における術前の $\mathrm{OKN}$ を 手術所見からみた腫瘍の進展範囲, 腫瘍の大き さなよ゙から検討してみた（表 8 ）。聴神経腫瘍 の 4 例についてみると，腫瘍の大きさは畒小 $25 \mathrm{~mm}$ ，最大 $40 \mathrm{~mm}$ であったが， $40 \mathrm{~mm}$ 人の㾁:例でも OKP はほぼ止常のパターンを示したが，緩徐 相速度は $60^{\circ} / \mathrm{sec}$ 程度であった。この症例で

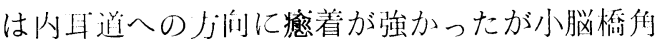
部)湢畴との癒着なく，症例 2,3 は $25 \mathrm{~mm} \sim 30 \mathrm{~mm}$ 大であったが小脳半球に接し，一部在迫し ていたあので，それぞれの OKP を示したが (図 7，8), とくに症例 3 では視標追従に対す る眼球括動緩徐相の発現に hypermetria を伴 い， overshoot の沂胃を示している． 滦例 4 （汹 9 ）では患側 OKN の緩徐相速度の低下が

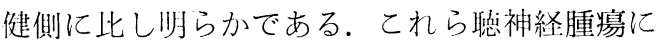

表 8 脳腫瘍例の病巣の拡がりと OKN 所見

\begin{tabular}{|c|c|c|c|c|c|c|c|}
\hline & 疾 & 年粭 & 性 & 患側 & 手 術 所 見 & 腫瘍の大きざ & OKN \\
\hline Case 1 & 聴神経腫瘍 & 39 & $\mathrm{~F}$ & 左 & $\begin{array}{l}\text { 小脳橋角部で癒着なく, } \\
\text { 上方 }(\mathrm{VII}) \text { への圧迫. } \\
\text { 内耳道の瘭着強度. } \\
\text { 下方 }(\mathrm{IX}, \mathrm{X}, \mathrm{XI}) \text { への進展なし. }\end{array}$ & $40 \mathrm{~mm}$ & ほぼ正常 \\
\hline Case 2 & " & 38 & M & 有 & $\begin{array}{l}\text { 小脳半球の内側に接す. } \\
\text { Pons の圧迫はない. }\end{array}$ & $25 \mathrm{~mm}$ & $\begin{array}{l}\text { Hyperreaction } \\
\text { 緩徐相速度の低下 }\end{array}$ \\
\hline Case 3 & " & 50 & M & $t_{\mathrm{r}}:$ & $\begin{array}{l}\text { Cystic の腫煬, 脳幹との癒着は少 } \\
\text { ないが, 小脳半球〜虫部の庄迫あ } \\
\text { り. }\end{array}$ & $30 \mathrm{~mm}$ & overshoot \\
\hline Case 4 & "I & 24 & $\mathrm{~F}$ & 左 & $\begin{array}{l}\text { 上方はV 神経に，下方は } \mathbb{X} \sim X \mathbb{X} \\
\text { 接する. } \\
\text { 癒着は少ない. }\end{array}$ & $30 \mathrm{~mm}$ & $\begin{array}{l}\text { 左右差あり } \\
\text { 左问き } \\
\text { 緩徐相速度の低下 }\end{array}$ \\
\hline Case 5 & 三义神経腫婸 & 35 & $\mathrm{~F}$ & 有 & $\begin{array}{l}\text { 峋側で中脳と接し尾側で } \mathrm{V} \text { 神経と } \\
\text { 高度癒着し, 脳幹を生迫. }\end{array}$ & $40 \mathrm{~mm}$ & 緩徐相速度の低下 \\
\hline Case 6 & " & 22 & M & $t_{i}$ & $\begin{array}{l}\text { VII, VIII神経に接し, 脳幹を圷迫. } \\
\text { 大きい cystic 腫煬, 左小脳半球 } \\
\text { を龙迫. }\end{array}$ & $30 \sim 40 \mathrm{~mm}$ & 解発不蛙 \\
\hline Case 7 & 第监脳至腫陽 & 42 & $\mathrm{~F}$ & 店: & $\begin{array}{l}\text { 腄瘍の下端は大後頭孔よりも下降. } \\
\text { 菱脳窩の下半分をほぼ全域を占有 } \\
\text { し, 吻側に伸展, 左側の側窩へ拡大. }\end{array}$ & $30 \mathrm{~mm}$ & 解発不㫰 \\
\hline Case 8 & 髄膜腫 & 35 & $\mathrm{~F}$ & 有 & $\begin{array}{l}\text { 小脳テントより発生した巨大腫痬 } \\
\text { で右外側端の中央部を中心に占め } \\
\text { る. }\end{array}$ & $40 \sim 50 \mathrm{~mm}$ & 緩徐相速度の低下 \\
\hline Case 9 & $\begin{array}{l}\text { 頸静脈孔腫湯 } \\
\text { (副神経鞘腫) }\end{array}$ & 58 & $\mathrm{~F}$ & 左: & $\begin{array}{l}\text { 上方はV 神経に達し, 脳幹部にも } \\
\text { 土迫. 腹側は錐体骨に及び, 下端 } \\
\text { は大後頭孔に達す. }\end{array}$ & $40 \mathrm{~mm}$ & 解発不良 \\
\hline
\end{tabular}


限定してみると，緩徐相速度が低速度から障瑟 されている点が共通した所罗としてみられ，患 側がより低速度からの障害が強く，腫瘍の進展 方们により，とくに小脳半球，脳幹への压迫が ある症例では緩徐相速度は低〜中速度で障㫪さ れ，対僛への dysmetria 走している. 脳幹 を压迫していた三叉神経腫煌の 2 例は OKP に て急速相の解発が高度に抑制され，緩徐相速度 も低速度から障夆されており，症例 5 では中脳 に愣し, 症例 6 は患側小脳半球在迫し, OKP は左右側と屯障㕩されていた（図10，11）。

その他の脳腫瘍として症例 7 の第四脳室腫瘍 は中脳に及汪巨大な腫瘍であり，低〜山速度の 緩徐相速度は障害が強く（図12），症例 8 は小 脳テントより発生した巨大なな䯑道膜腫で, 低速度 よりの緩徐相速度に障害がみられ（図13），症: 例 9 の神経鞘腫は上方, 内方腹側にわたり脳幹 部にも压迫して抢り OKP は解発不良であっ た (図|14)。

\section{拢子㥞回転腿振}

視運動刺激と回転刺激と併せた振子柡回転検 查にて解発される眼振につき，小枢性めまい怔 例44例を対象之し（表 9 ）一点注:視，西酒祝， 閉眼，遮眼の各条件にて観察した。中枢性障㕩 例では波形の乱机，眼振リズムの乱れが特微的 であり，注視条件としては一点注視，正酒視に おける異常所見が高率にみられた。また脳幹障 害を伴う小脳橋角部病変例では各種条件でいず れ屯眼振左右差走し，患側への眼振急速相の 解発に異常 (抑制) がみとめられた。

4) 中枢性めまい症例に打ける血液化学検查 所㫕

中枢性めまい症例のなかで脳動脈㹬化症例 (28例), 椎骨脳底動脈循環不全（25例）に対し 血液生化学的検查を行った。検查项目は赤任 球, 白血球，へモグロビン，へマトクリット， フィブリノーゲン, 総コレステロール, 中性脂 肪，血糖などであるが，これら脸循環不全例の
大部分において赤血球 500 う以上， ヘマトクリ ット $45 \%$ 以上，フィブリノーゲン $300 \mathrm{mg} / \mathrm{dl}$ 以 上を示し，全症例の63.6\%がこれら血液生化学: の検査のうち一項目以上に異常值を示した。乙 のうち脳血管撮影を行って著しい血管の狭小が みられた将例の血液化学の成績を表10に一括し た。このように脳循環不全に起因するめまいは 脳動脈系（椎骨脳底動脈采屯含屯）の形態異常 に加えて血液所見の異常, 即ち赤血球の增多, 凝润系の元進，脂質代謝異常などに起因した片 液粘稠度の増加と相俟って血流障害をきたし多 く, 脳血流量に異常を招きめまい誘発に至るも のと思われる。

\section{まとめ}

今回取り报ったい枢性めまい族患において神 䋂耳科学的な圤場から綜説を述べてきたが，女 まいの診断に対する恥覚系, 前庭系のアプロー チは車の両輪の如く臨床上極めて重姦であるこ とは凮知の通りで，近年の恥覚検查の進少によ り川枢性病変の診断も可能となってきている. なかで屯聴性脳幹反心の有用性は高く評価さ れ，脳腫愓例には不可火な検査法といえる。

めまい疾患は神経学的手法に方肪した将態診 断法が大切であるが，検査に先少ってまず䦌彰 の車要性老強調したい。奴い・平衡障暃とい えども楜切な問診を行えば，ある程度のめまい 病態やめまいの背景因子屯解明され，次いでT! 桉なポイントは眼球運動を正:しく把握すること と思われる。

これら瀶休実地における基本的な診断法を踏 まえ，続いてその毫付けとなる検查（精密恥 覚, 平衡機能検査, 画像診断, 血液化学検烃な ど）に進むべきであろう。

聴神経腫瘍はそれほど稀な发患ではないと思 われるが，なかには笑発難恥として取り扱わ れ，年余に打たり放置されていた症例にも遭遇 しているが，郚休家として私其条自が心すべき 㰡患の-.つと言えよう。 

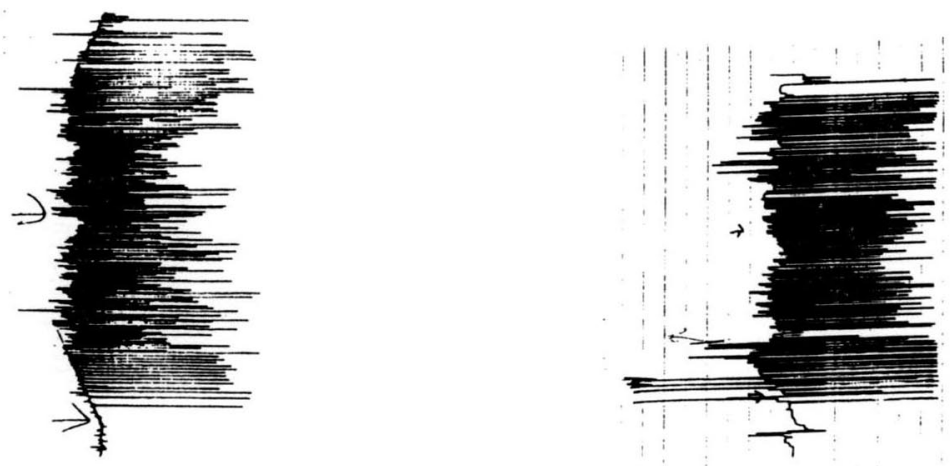

농

ํํㅇ
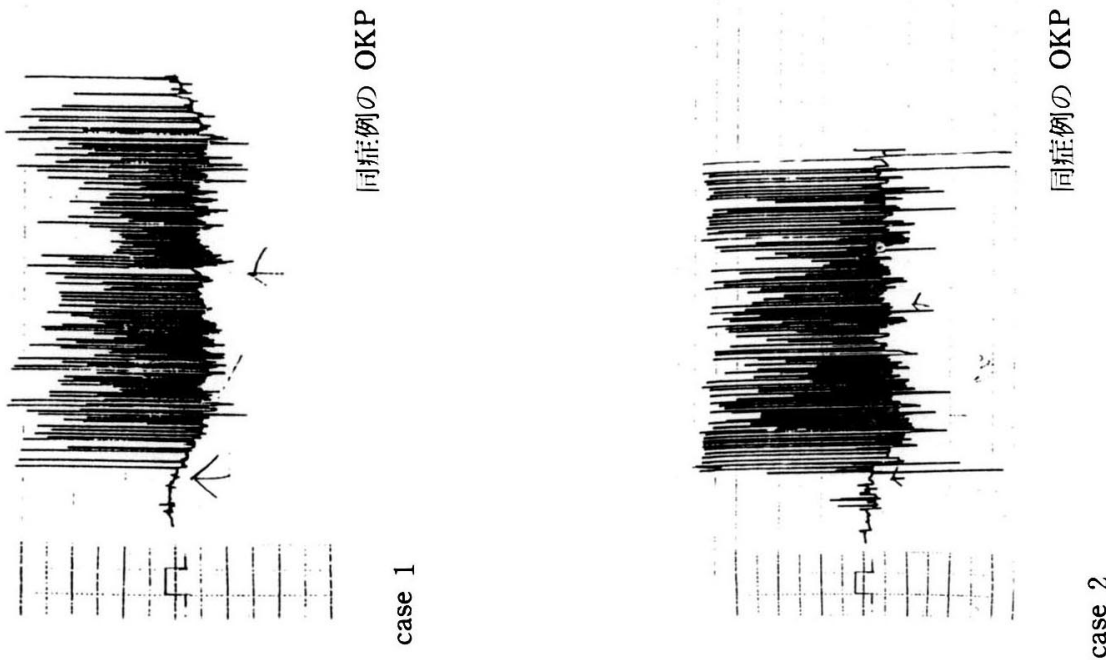

国
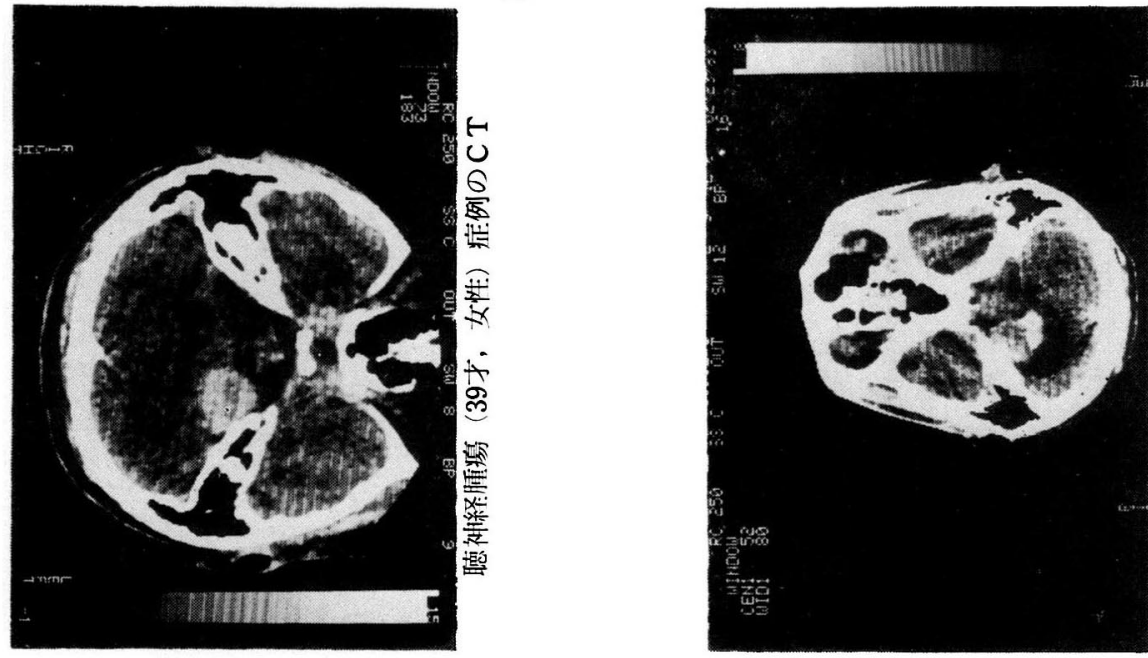

ֻ

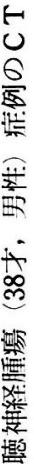



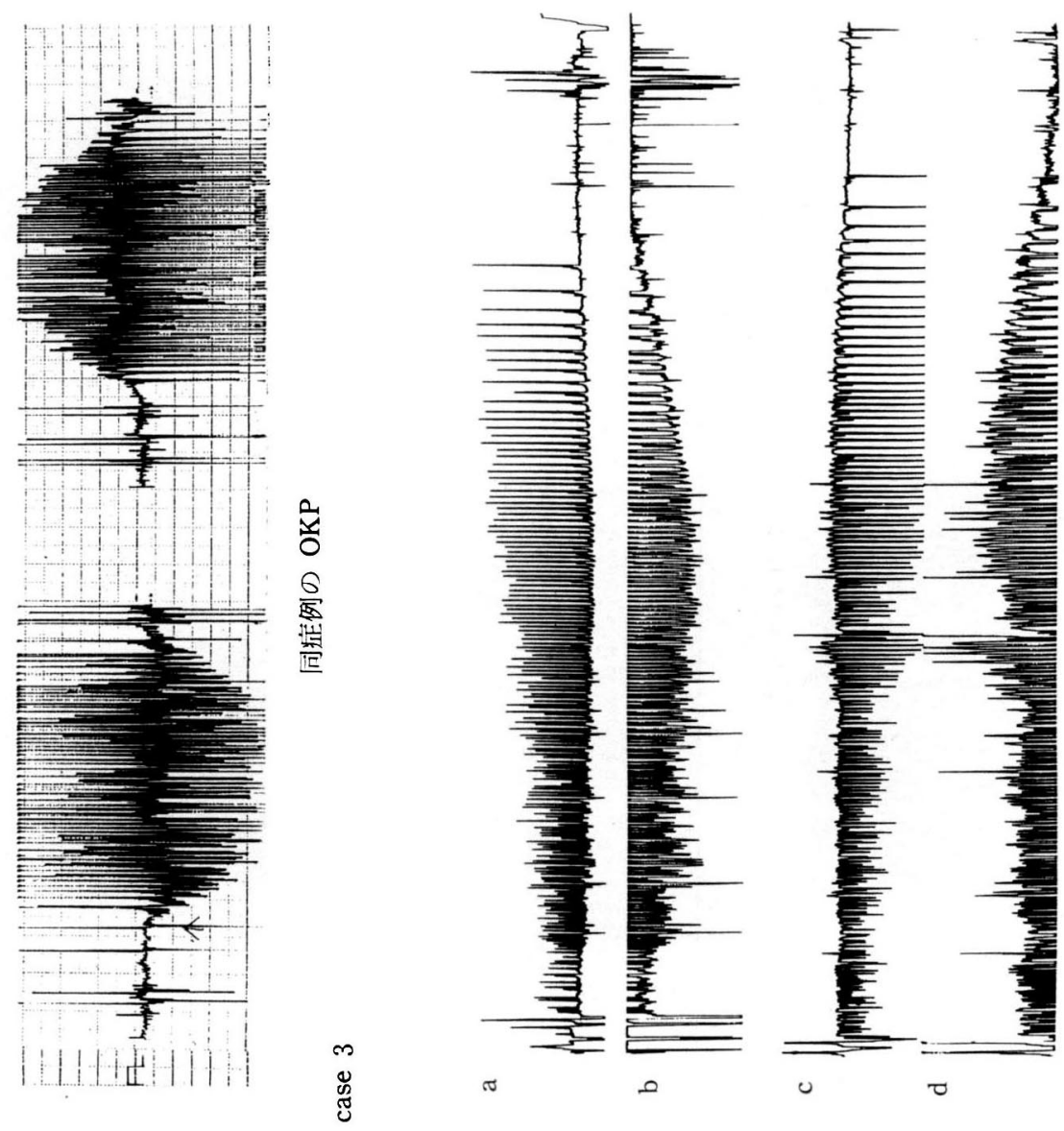

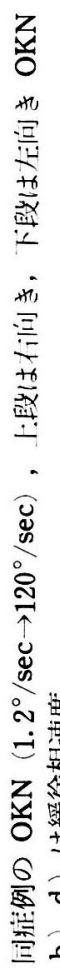

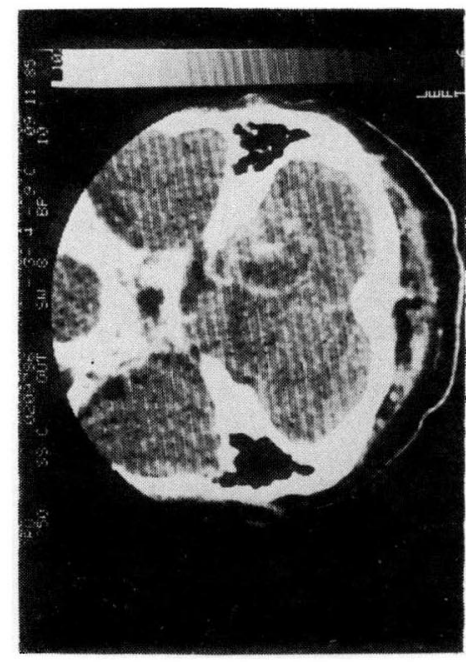

四

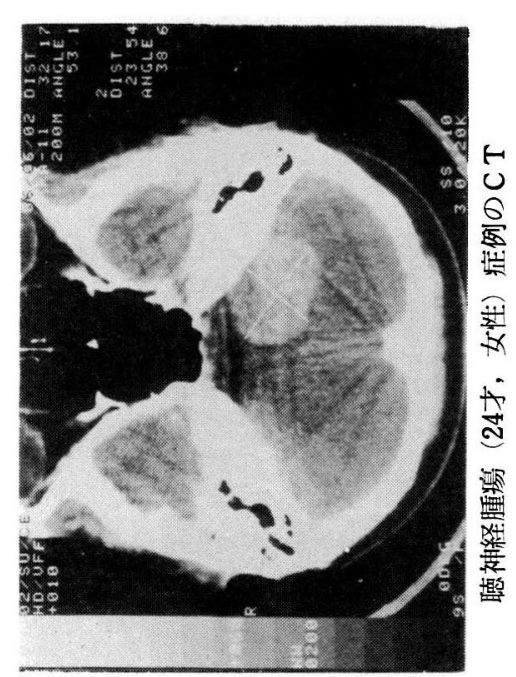

o

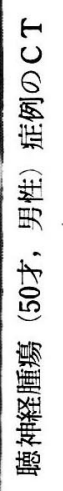



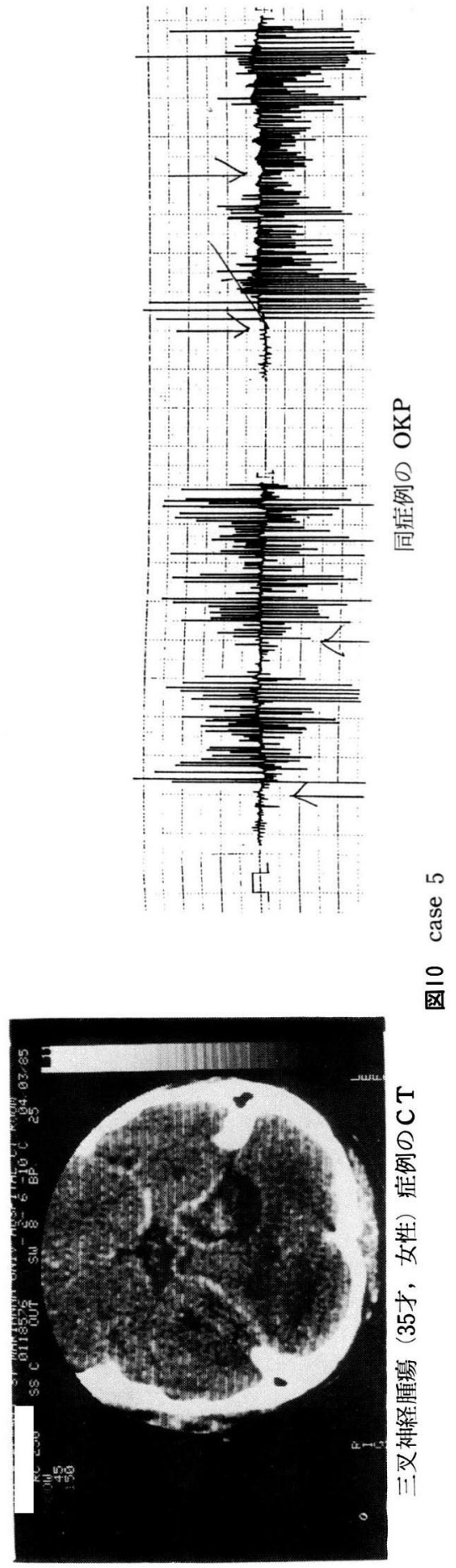

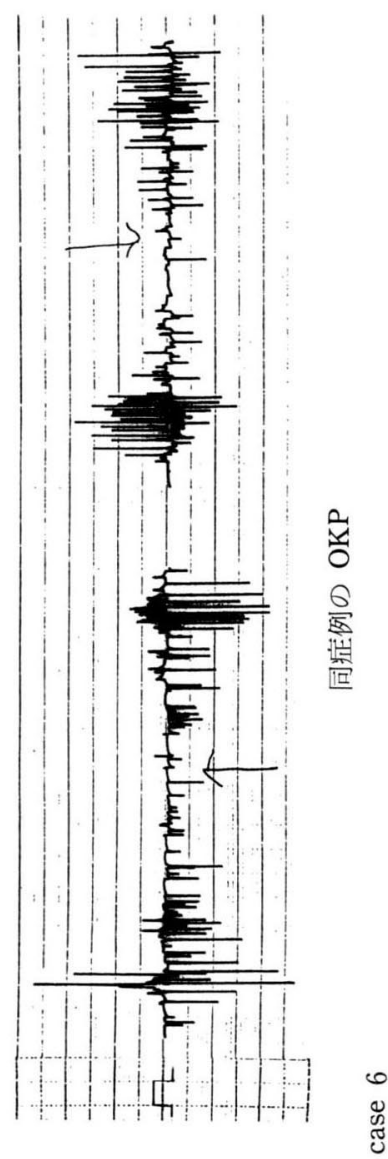

三

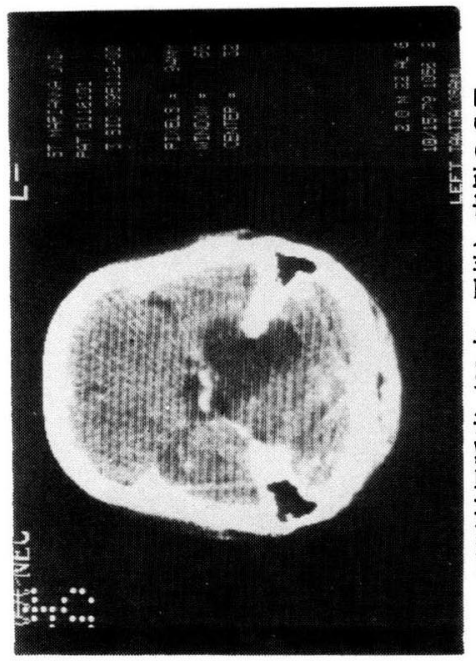



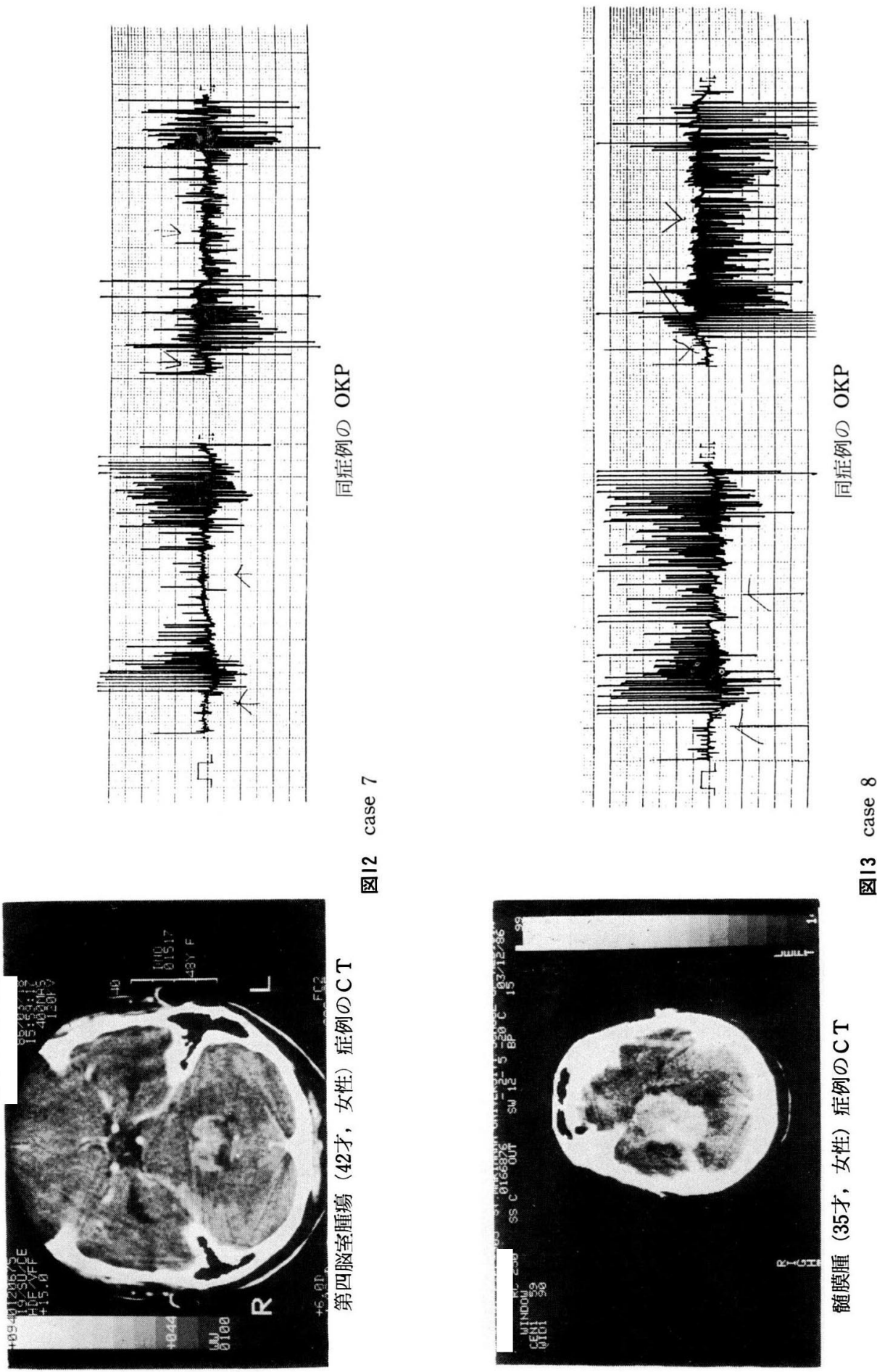
表 9 振子椂回転眼振検査を施行した対象と所見

\begin{tabular}{|c|c|c|c|c|c|c|c|c|}
\hline 注視 & 症 例 & $\begin{array}{c}\text { 正常例 } \\
(10)\end{array}$ & $\begin{array}{c}\text { 大脳障害 } \\
\text { (3) }\end{array}$ & $\begin{array}{c}\text { 椎骨絾底動 } \\
\text { 脈環不全 } \\
(3)\end{array}$ & $\begin{array}{l}\text { 春髄小临 } \\
\text { 変性症 } \\
\text { (3) }\end{array}$ & $\begin{array}{l}\text { 兴血管 } \\
\text { 障 } \\
\quad(15)\end{array}$ & $\begin{array}{c}\text { 小脳障害 } \\
\text { (8) }\end{array}$ & $\begin{array}{l}\text { 小脳橋角 } \\
\text { 部 障 害 } \\
\text { (10) }\end{array}$ \\
\hline 一占注 & 正 弦 波 & 10 & 0 & 1 & 0 & 11 & 3 & 5 \\
\hline 点诖 & 眼 振 解 発 & 0 & 0 & 0 & 0 & 0 & 0 & 0 \\
\hline 正 & 眼 振 解 発 & 10 & 3 & 3 & 3 & 15 & 8 & 10 \\
\hline 面 & 眼 振 左 右 差 & 0 & 1 & 2 & 2 & 2 & 5 & 2 \\
\hline 視 & リズムの乱れ(†) & 0 & 0 & 0 & 1 & 3 & 2 & 0 \\
\hline 閉 & 眼 振 解 発 & 5 & 2 & 2 & 1 & 9 & 5 & 5 \\
\hline & 眼振左右差 & 0 & 0 & 1 & 1 & 0 & 0 & 2 \\
\hline 眼 & リズムの乱れ(†) & 4 & 2 & 2 & 1 & 6 & 4 & 5 \\
\hline 開 & 眼 振 解 発 & 8 & 3 & 3 & 3 & 14 & 8 & 9 \\
\hline 眼算 & 眼 振 左 右 差 & 0 & 2 & 2 & 2 & 2 & 4 & 3 \\
\hline 荷 & リズムの乱れ(+) & 4 & 1 & 0 & 1 & 7 & 2 & 4 \\
\hline 遮 & 眼 振 解 発 & 10 & 2 & 3 & 2 & 13 & 6 & 8 \\
\hline & 眼振左右差 & 0 & 1 & 1 & 2 & 1 & 1 & 2 \\
\hline 眼 & リズムの乱れ(†) & 4 & 1 & 0 & 1 & 10 & 3 & 6 \\
\hline 遮 & 眠 振 解 発 & 10 & 3 & 3 & 3 & 15 & 8 & 9 \\
\hline $\begin{array}{l}\text { 眼算 } \\
\text { 暗負 }\end{array}$ & 眠振 左右差 & 0 & 2 & 3 & 2 & 2 & 6 & 5 \\
\hline 荷 & リズムの乱れ(+) & 4 & 1 & 1 & 2 & 10 & I & 3 \\
\hline
\end{tabular}
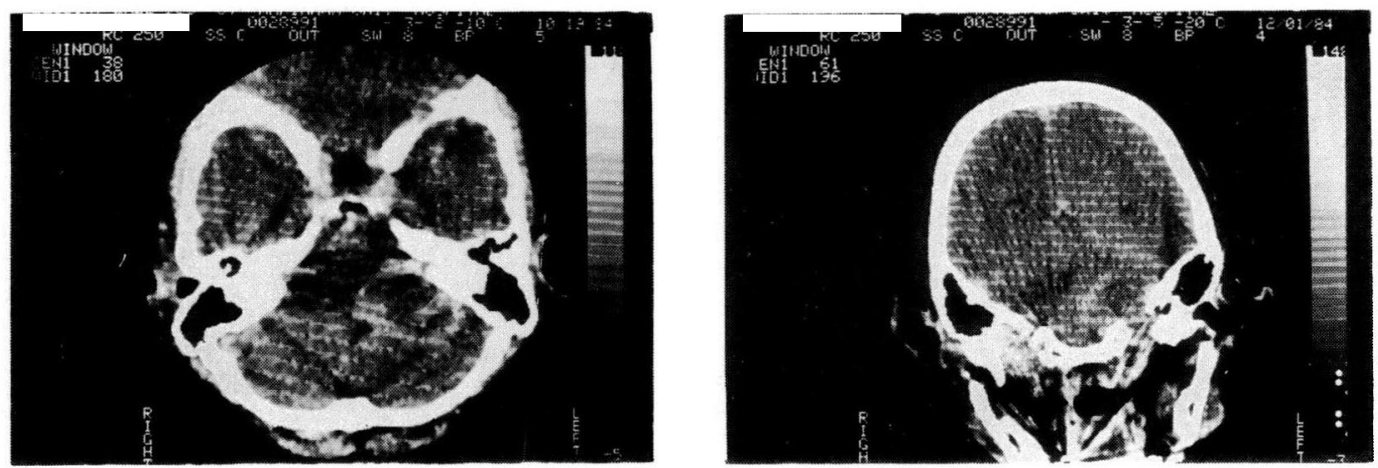

頙静脈孔腫劶（58才，女性）症例の C T
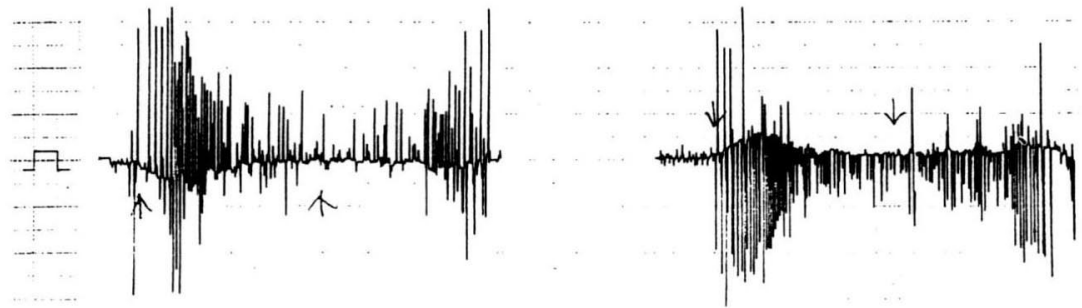

同应例の OKP

図14 case 9 


\section{むすび}

1 ）中枢性めまい病変は多彩であるが，適切 な問診は極めて大切である。

2 ）めまいの他覚的評価として偏倚，立直り の検査法も捨て難いものといえる.

3 ) 眼球運動検査法を駆使し, 眼球急速相の みならず緩徐相の所見も重視すべきものと考え ている

4 ）脳循環不全症といわれるめまい疾患の病
態には血液の粘椆度の亢進に基づく脳血流動態 の障害む考慮される。

5 ）神経耳科学的検査には前庭系と併せ聴覚 系の所見が示す意義も大きい.

6 ）めまい症例に対しては長期の経過観察や 定時的な追跡精查を㤐ってはならない，末梢性 めまいとして取り扱われている症例にも中枢性 病変が見落されていることああるので，経過の 推移を注意深く留意することが肝要である。

表10 中枢性めまい症例における血液化学検査值

Laboratory results

\begin{tabular}{|c|c|c|c|c|c|c|c|c|c|c|}
\hline \multirow{2}{*}{$\begin{array}{c}\text { Case } \\
\text { no. }\end{array}$} & \multirow[t]{2}{*}{$\mathrm{RBC}$} & \multirow[t]{2}{*}{ WBC } & \multirow{2}{*}{$\begin{array}{l}\mathrm{Hb} \\
(\mathrm{gm})\end{array}$} & \multirow{2}{*}{$\begin{array}{l}\mathrm{Ht} \\
(\%)\end{array}$} & \multirow{2}{*}{$\begin{array}{c}\text { Fib } \\
(\mathrm{mg} / \mathrm{dl})\end{array}$} & \multirow{2}{*}{$\begin{array}{l}\text { Cho- } \\
\text { lesterol } \\
(\mathrm{mg} / \mathrm{dl})\end{array}$} & \multirow{2}{*}{$\begin{array}{l}\text { Neutral } \\
\text { fat } \\
(\mathrm{mg} / \mathrm{dl})\end{array}$} & \multirow{2}{*}{$\begin{array}{l}\text { Blood } \\
\text { glucose } \\
(\mathrm{mg} / \mathrm{dl})\end{array}$} & \multicolumn{2}{|c|}{ Normal Range } \\
\hline & & & & & & & & & RBC $\left(\times 10^{6}\right)$ & M4. 1-5. 3 \\
\hline 1 & 590 & 4700 & 16.7 & 49.3 & 310 & 183 & 83 & 97 & WBC $\left(\times 10^{3}\right)$ & $M_{1-8}$ \\
\hline 2 & 460 & 5800 & 15.5 & 50.4 & 420 & 171 & 96 & 86 & $W D C\left(\times 10^{\circ}\right)$ & $F^{4-8}$ \\
\hline 3 & 516 & 6000 & 14.7 & 48.4 & 340 & 277 & 116 & 81 & $\mathrm{Hb} \quad(\mathrm{gm})$ & M14-18 \\
\hline 4 & 503 & 5900 & 14.7 & 49.5 & 380 & 248 & 102 & 87 & & \\
\hline 5 & 476 & 6200 & 13.8 & 46.8 & 410 & 186 & 98 & 87 & Ht. $(\%)$ & $\begin{array}{l}\mathrm{M} 440-48 \\
\mathrm{~F} 34-42\end{array}$ \\
\hline 6 & 427 & 5800 & 12.7 & 39.7 & 330 & 216 & 108 & 102 & Fib. $(\mathrm{mg} / \mathrm{dl})$ & $200-400$ \\
\hline 7 & 469 & 9900 & 15.5 & 48.4 & 290 & 194 & 86 & 92 & Cholesterol & $110-260$ \\
\hline 8 & 486 & 7400 & 15.7 & 49.1 & 410 & 256 & 126 & 84 & $(\mathrm{mg} / \mathrm{dl})$ & $110-200$ \\
\hline 9 & 562 & 5300 & 15.0 & 52.3 & 420 & 268 & 106 & & $\begin{array}{l}\text { Neutral fat } \\
(\mathrm{mg} / \mathrm{dl})\end{array}$ & $55-155$ \\
\hline 10 & 433 & 6300 & 13.4 & 40.5 & 310 & 170 & 94 & 151 & & \\
\hline 11 & 483 & 6100 & 14.8 & 49.7 & 430 & 308 & 154 & 101 & $(\mathrm{mg} / \mathrm{dl})$ & $70-100$ \\
\hline
\end{tabular}

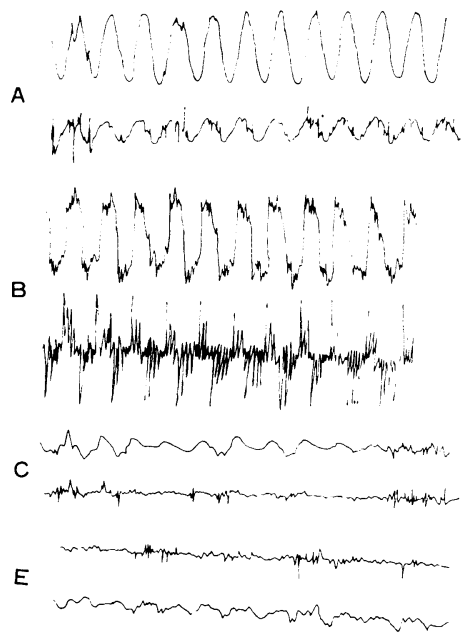

75才 男性 大脳障害

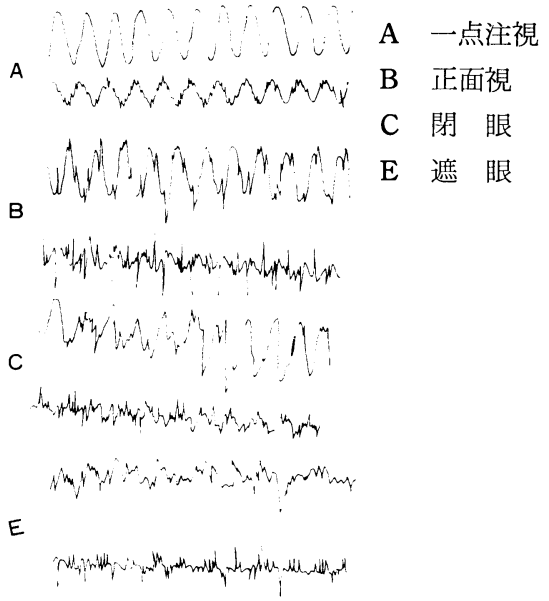

53才 男性 雸髄小脸変性症例 図15 振子様回転眼振の所見 


\section{文献}

1) 檜 学: 前庭機能検査之治療 (宿題報告要旨). 日耳鼻 $62 ： 2625 \sim 2628 ， 1959$.

2 ) Bender MB, et al: The oculomotor system. Hoeber, 1964.

3) 竹山 勇, 他：脸腫瘍症例の術前術後における眼 球運動に関する経時的観察. 聖マリアンナ誌 4 : 98〜112, 1976.

4）切替一郎編：中枢神経障害へのアプローチー身体
の平衡・きとえとととば一. 金原出版, 東京, 1973.

5 ) 鈴木淳一監：ABR マニュアル一聴性脳幹反応の 臨床応用一。篠原出版, 東京, 1984.

$$
\left(\begin{array}{l}
\text { 別刷請求先 : 竹山 勇 } \\
\text { T213 川崎市宮前区菅生 } 2-16-1 \\
\text { 聖マリアンナ医科大学耳鼻咽喉科学教室 }
\end{array}\right)
$$

